\title{
実務設計における木質ラーメン A STUDY OF THE STRUCTURAL の構造解析に関する一考察 ANALYSIS FOR TIMBER FRAME ON ACTUAL DESIGN
}

\author{
景山 誠— * 1 村上雅英 — $* 2$ \\ キーワード : \\ 木質ラーメン，数值解析，鉛直荷重，勒性，危険断面位置 \\ Keywords: \\ Moment resistance timber frame, Numerical analysis, Vertical load, \\ Ductility, Critical section position
}

\section{Makoto KAGEYAMA $-* 1 \quad$ Masahide MURAKAMI $-* 2$}

This paper elucidated two problems to calculate the structural performance evaluation of the moment resistance timber frame ("frame") with a vertical load by structural analysis on actual design. Problems as follows; ultimate strength of the frame that connection is brittle, and frame structural performance that critical section position of columnbeam connection is not on structural axis. For numerical analysis, it is confirmed that ultimate strength of the frame is fallen because of a vertical load, and critical section position should evaluate appropriate position for each connection specification.
1.はじめに

現在、木造住宅を対象として様々な仕様の木質ラーメンがある が、それらの多くには以下の問題点がある。

木質ラーメンのせん断耐力 $\mathrm{P}_{0}$ は、終局耐力 $\mathrm{P}_{u}$ と塑性率 $\mu$ で求ま

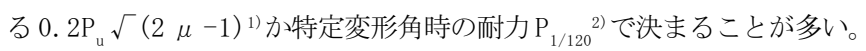
木質ラーメンの構造性能を試験で求める場合、試験装置の制約で特 定のスパンや階高に対して梁に鉛直荷重を載荷しないケースが多 い。また、実際は鉛直荷重を負担寸ると $\mathrm{P}_{\mathrm{u}}$ も下がるため、 $\mathrm{P}_{0}$ を数值 解析で求める場合は弾性範囲のみでなく終局状態も含めた弾塑性解 析で評価すべきである。よって $\mathrm{P}_{0}$ が $\mathrm{P}_{1 / 120}$ で決まるとみなして弾性解 析のみで評価するのは、必ずしも安全側とはいい難い。一方、複合 応力状態の接合部の構造性能を試験から評価する場合、危険断面位 置は仕様毎で異なるが、回転バネを危険断面位置に設けるため剛域 を設定することで適切に評価できることが既報 ${ }^{3)}$ で明らかとなった。 文献 3 ) では、本報で対象と寸る金物で構成される接合部や、ラグス クリューボルト（LＳＢ）接合部で検討しており、後者は特に剛域 を長く設定する必要性が指摘されている。また、剛域を設定する力 学的根拠は、接合部内でせん断力が木材から金物へ伝達される抵抗 機構に起因する。よって、金物を用いる接合部は、せん断力が構造 芯で伝達される抵抗機構でない限り、このように剛域を設定する評 価が必要と考えられる。また、接合部の性能を試験で評価する際の せん断スパンの適切な長さを明確に示した規準もない。

しかし、実務設計で木質ラーメンの構造性能を評価する場合、ス パンや階高の違いや鉛直荷重の影響が無視されているケースもあ る。また、これらが考慮されていたとしても、接合部内でせん断力
が伝達される位置を危険断面位置とし、この位置に回転バネを設け て評価することを記した規準がない。そのため実務では、数值解析 を用いる場合に、接合部の回転バネの適切な位置を十分に検討せず に設計される場合もあるのが現状である。

よって本報では、実務設計で行われている上記の方法の妥当性を 確認するため、下記の検討を数值解析で行い考察を述べる。(1) : 鉛 直荷重の有無による木質ラーメンの終局時のせん断耐力の差異を、 接合部の勒性を変数として検討寸る。(2)：危険断面位置が柱梁部材 の構造芯とならない仕様の柱頭接合部を想定し、せん断スパンを変 数として接合部の復元力特性を求め、危険断面位置を適切な位置と した場合と構造芯とした場合の比較を行う。これらの検討と考察は 5 章で行う。そのために必要な試験や解析として、鉛直荷重の有無 を変数として木質ラーメンの水平加力試験を行い、その影響を 3 章 で述べる。また、解析結果を試験結果と比較し、終局状態を含めて 数值解析で木質ラーメンの挙動をどの程度再現できるかの検討を 4 章で行う。以降、本報で「架構」は木質ラーメンを指す。

\section{2. 対象とする木質ラーメンの仕様ならびに既報 ${ }^{3)}$ の概要}

柱頭・柱脚接合部は、図 1 のように在来軸組工法用の鋳鉄製金物 2 個と木材をドリフトピンで接合して組立てる。木材は E $120-$ F 330 等級の対称異等級構成集成材、樹種はオウシュウアカマツ とし、柱断面は $120 \times 240 \mathrm{~mm}$ 、梁断面は $120 \times 330 \mathrm{~mm}$ である。柱頭接 合部の柱と梁受金物は六角ボルトでつなぎ、試験体製作時は経年変 化による緩みを考慮し $20 \mathrm{Nm}$ のトルクでナットを弱く締め付けた。 本報で対象とする木質ラーメン接合部について、既報 ${ }^{3)}$ では柱

\footnotetext{
近畿大学大学院総合理工学研究科環境系工学専攻 大学院生 - 工修

(干 577-8502 東大阪市小若江 3-4-1)

2 近畿大学理工学部建築学科 教授・工博
} 


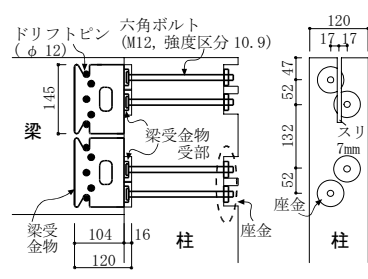

(a) 柱頭接合部 $[\mathrm{C} \mathrm{T}]$

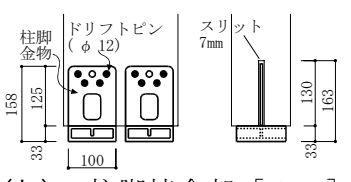

(b) 柱脚接合部 $[\mathrm{C}$ B $]$

図 1 接合部仕様

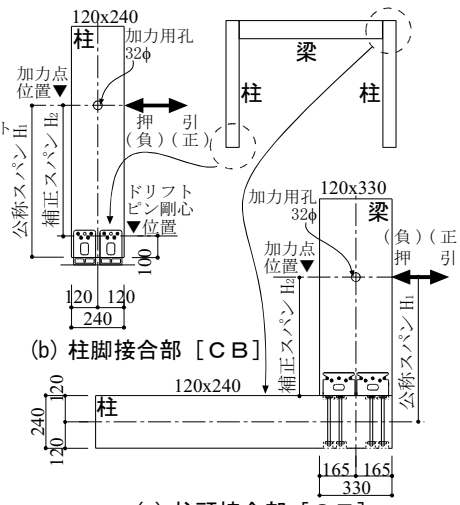

(a) 柱頭接合部 [ $\mathrm{C}$ T ]

図 2 要素試験用試験体仕様

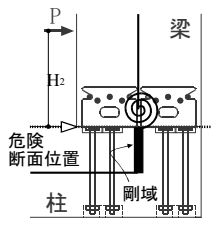

(a) 柱頭接合部

[ C T ]

図 3 接合部のモデル化

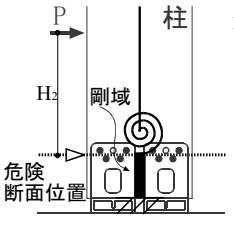

(b) 柱脚接合部 C B ] $\mathrm{M}(\mathrm{kNm})$

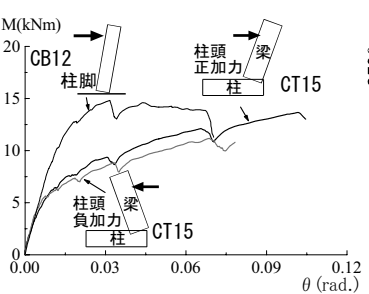

図 5 各接合部の $M-\theta$ 関係

頭・柱脚接合部を抽出した図 2 の要素試験体で、曲げとせん断の複 合応力試験や、純曲げ・純せん断の基準耐力試験（以降、要素試験） を行い、危険断面位置に回転バネを設けるため剛域を設定するモデ ル化により、せん断スパンによらず曲げ耐力が適切に評価できるこ とを示した。本接合部の危険断面位置は、図 3 のように柱頭接合部 では柱側面、柱脚接合部ではドリフトピンの剛心位置であることを 一連の試験で見出した。これらの位置は、接合部内でせん断力が金 物或いは他方の部材へ伝達される位置である。また本接合部の構造 性能は、図 3 のように剛域を設定した補正スパン $\mathrm{H}_{2}$ で評価すること で、複合応力試験で得た柱頭・柱脚接合部の降伏耐力、最大耐力は 複合応力の検定式 (1) の $\mathrm{n}=2$ に概ね近くなることを示した。紙面 の都合上、文献 3 ) に掲載した柱脚接合部の最大耐力時の結果を、剛 域を設定した L S B 柱脚接合部の結果と合せて図 4 に示す。

$$
\left(M_{d} / M_{a}\right)^{n}+\left(Q_{d} / Q_{a}\right)^{n} \leq 1
$$

(Mは曲げモーメント、Qはせん断力、添え字 $\mathrm{d}$ は作用する力、添 え字aは純曲げ又は純せん断状態での許容耐力。)

ここでは複合応力試験の結果の一例として、図 2 の公称スパン $\mathrm{H}_{1}$ が柱頭で $1500 \mathrm{~mm}$ （試験体名 C T 15 ）、柱脚で $1200 \mathrm{~mm}$ （試験体名 C B 12 ）での、試験結果を補正スパン $\mathrm{H}_{2}$ で評価した曲げモーメント 一回転角関係 $(\mathrm{M}-\theta$ 関係) の平均の包絡線を図 5 に示す。

\section{3. 木質ラーメンの水平加力試験}

\section{1 試験概要}

鉛直荷重の有無を実験変数とした木質ラーメンの水平加力試験を 行った。鉛直荷重は、柱頭接合部が長期で許容曲げモーメント $M_{L y}$ となる荷重を予め数值解析で求めた。 $M_{L y}$ は、既報 ${ }^{3)}$ の要素試験から 完全弹塑性評価 ${ }^{4}$ による短期基準曲げモーメント $\mathrm{M}_{\mathrm{S} Y}$ に $1.1 / 2$ を乗じ て求めた。なお、本報での低減係数 $\alpha$ は 1.0 とした。

試験概要を図 6 に示す。試験体のスパンは $4 \mathrm{P}$ 、樹種や仕様は 2 章と同一で試験は鉛直荷重なし $(4 \mathrm{P}-0-1 \sim 3)$ 、鉛直荷重 $45 \mathrm{kN}$ $(4 \mathrm{P}-45-1 \sim 3)$ の 2 通り実施し、試験体数は各 3 体とした。

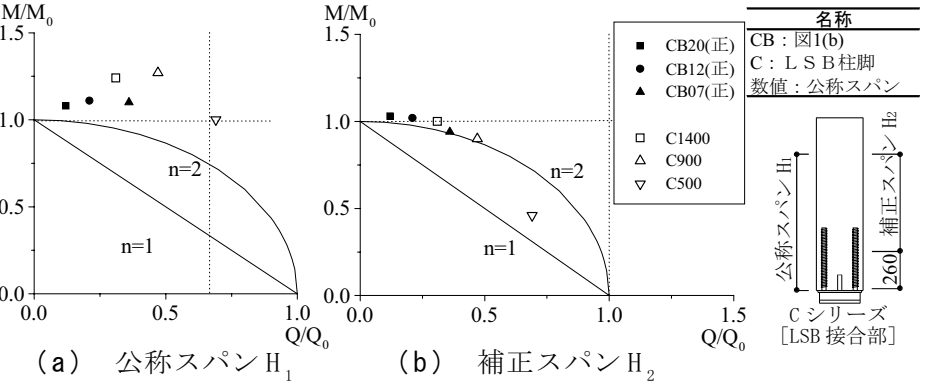

図 4 複合応力の検定一覧（平均值）

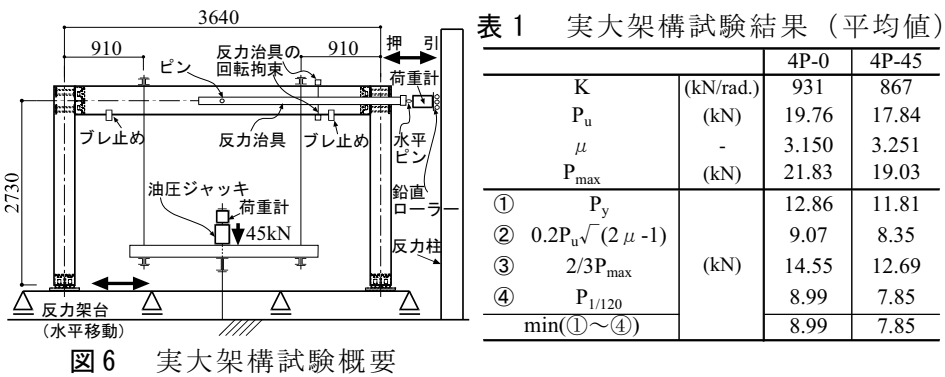

試験は、図 6 のように梁と反力柱をピンと鉛直ローラーで接合し、 柱脚金物を固定した反力架台を水平移動させて加力した。梁に作用 させる鉛直荷重は常に一定值となるよう、油圧式アクチュエーター で荷重制御している。また、鋁直荷重用の加力装置は水平加力装置 から独立しているので、実際と同じように鉛直荷重を梁の鉛直方向 に載荷しながら水平加力できる。加力履歴は、制御変形角を $1 / 600$ 、 $1 / 450 、 1 / 300 、 1 / 200 、 1 / 150 、 1 / 100 、 1 / 75 、 1 / 50 、 1 / 30 、 1 / 15 、 1 /$ $10 \mathrm{rad}$. の正負交番 3 回繰返し漸増載荷とした。

\section{2 試験結果}

各試験体の荷重一変形角関係 $(\mathrm{P}-\mathrm{R}$ 関係 $)$ の包絡線を図 7 に、 各特性值の平均値を表 1 に示寸。架構の耐力評価時の終局変形角 $\mathrm{R}_{\mathrm{u}}$ の上限は $1 / 15 \mathrm{rad}$ ，とする。図 7 より、鉛直荷重なしの荷重は最大耐 力以降ほとんど低下しない。この理由の 1 つとして、図 5 のように 柱頭接合部は降伏後も緩やかに耐力が上昇し続けるのに対し、柱脚 接合部は最大耐力以降に低下寸るため、両者の耐力が相殺されるこ とが挙げられる。また、最大耐力以降の架構の荷重低下の度合い は、鉛直荷重ありの方が顕著であった。短期基準せん断耐力（ $\mathrm{P}_{0} ）$ は鉛直荷重の有無によらず特定変形角時の耐力 $\left(\mathrm{P}_{1 / 120}\right)$ で決定し、 各特性值は鉛直荷重ありの方が低かった。

\section{3 鉛直荷重の影響による考察}

本報では、鉛直荷重が木質ラーメンのせん断耐力に与える影響を 次の 2 点に着目して検討する。

\section{3. 1 各接合部の降伏による影響}

図 8 に各接合部が降伏モーメント $\mathrm{M}_{\mathrm{y}}$ に達した時のプロットと、架 構の荷重一変形角関係の一例を示寸。各接合部の危険断面位置の曲 げモーメントは図 8 (c) の柱に貼付したひずみゲージから推測した架 構のモーメント分布から求め、 $\mathrm{M}_{\mathrm{y}}$ は 4.2 で述べる復元力特性とし た。鉛直荷重なしでは各接合部の降伏時期は比較的近いのに対し、 鉛直荷重ありでは水平力で梁の上側が引張側となる接合部が、鉛直 荷重による曲げモーメントのオフセット分だけ早期に降伏した。こ の現象が架構に与える影響は $\mathrm{P}-\Delta$ 効果と併せて次に述べる。

\section{3. $2 P-\Delta$ 効果の影響}

架構の水平加力試験では、図 7 のように最大耐力以降の耐力低下 


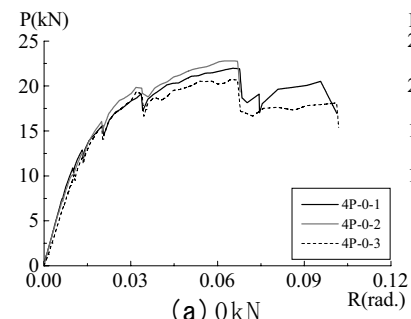

(a) $0 \mathrm{kN}$

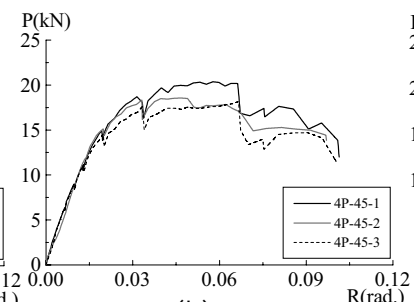

(b) $45 \mathrm{kN}$

図 $7 \quad \mathrm{P}-\mathrm{R}$ 関係一覧

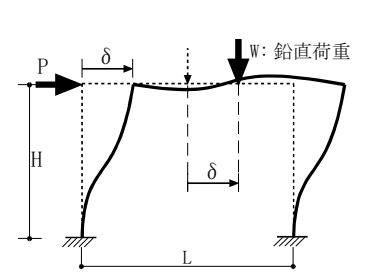

図 9 鉛直荷重を負担する 架構の力のつりあい

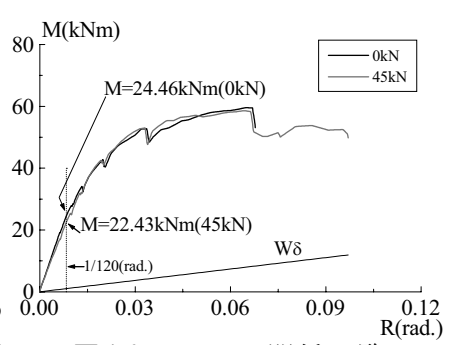

図 $10 \mathrm{M}-\mathrm{R}$ 関係一覧

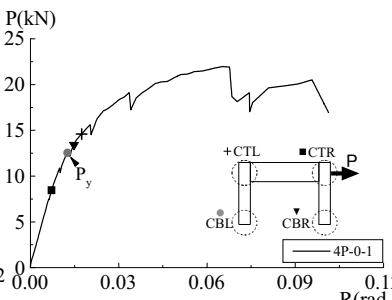

(a) $0 \mathrm{kN}$

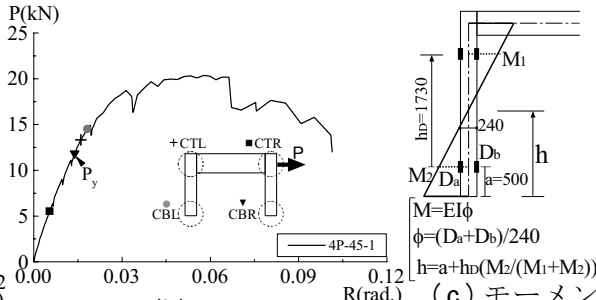

(b) $45 \mathrm{kN}$

図 8 接合部の降伏と $\mathrm{P}-\mathrm{R}$ 関係一覧 卜の算定

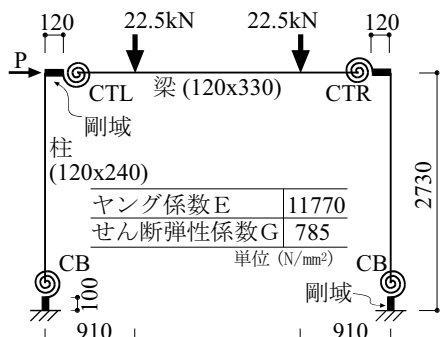
$+910$

3640 図 11 解析モデル

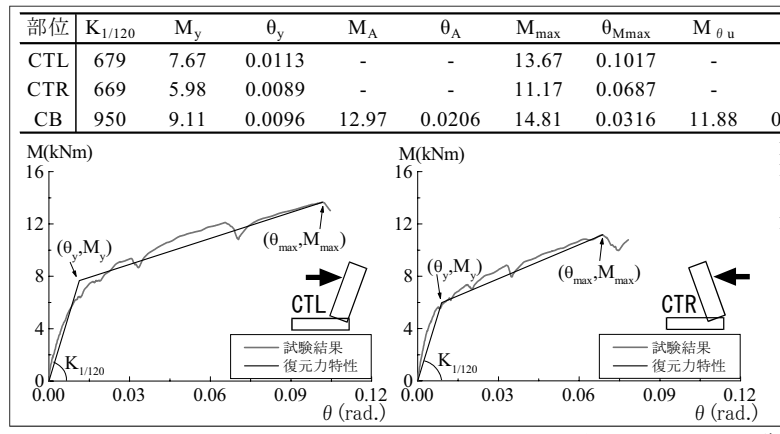

図 13 復元力特性一覧

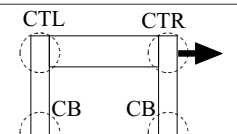
$\mathrm{M}(\mathrm{kNm})$

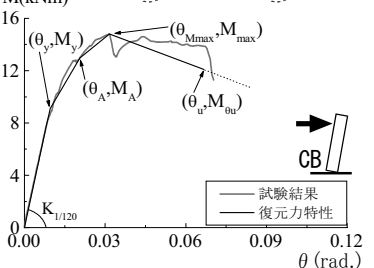

$\mathrm{M}(\mathrm{kNm})$

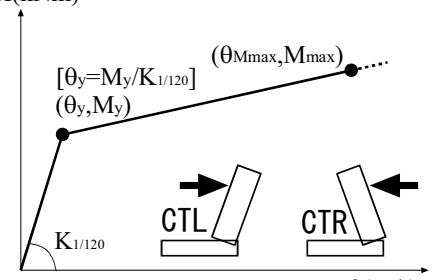

（a）柱頭接合部

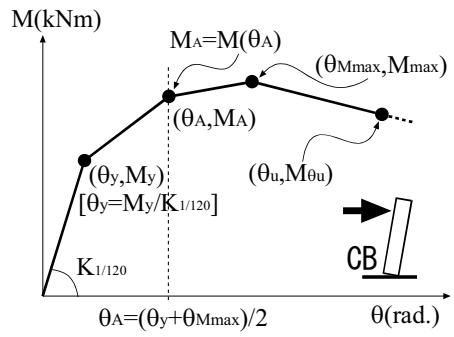

(b) 柱脚接合部

図 $12 M 、 \theta$ の座標

の割合は、鉛直荷重ありの方が大きい。図 9 より、 $\mathrm{P}-\Delta$ 効果を考 慮した架構全体に作用するモーメントは、

$$
M=P H+W \delta
$$

となる。図 10 に、式（2）で求めた架構全体のモーメント一変形 角関係 $(\mathrm{M}-\mathrm{R}$ 関係）の、鉛直荷重の有無での平均の包絡線を示寸。 また、 $\mathrm{P}-\Delta$ 効果の影響を表す鈶直荷重 $\mathrm{W}$ と変位 $\delta$ の積も併せて示 す。架構全体の曲げモーメントで評価すると、 $\mathrm{P}-\Delta$ 効果のみであ れば鉛直荷重の有無による差はない。しかし、図１０のように $1 /$ $120 \mathrm{rad}$. 時の架構全体のモーメントは荷重ありの方が $8 \%$ 程度低いた め、 $\mathrm{P}-\Delta$ 効果以外の影響があると考えられる。これは 3 ． 3． 1 の知見より、鉛直荷重の影響で接合部が早期に降伏していることか ら、1/120 rad. 付近での架構のせん断耐力は、接合部の降伏による 架構の剛性低下の影響といえる。この時、架構の同一変形角時にお いて、鉛直荷重なしよりありの方が、水平加力時に梁の下端が引張 側となる開く側の柱頭接合部では、鉛直荷重により回転角は小さく なり負担するモーメントも小さくなるのに対し、早期に降伏する閉 じる側の回転角は大きくなる。また、本報で対象とした柱頭接合部 は、降伏以降も耐力が緩やかに上昇する。よって、鉛直荷重ありで の架構の耐力低下には、柱頭接合部が開く側のモーメントや回転角 の影響はほとんどないと考えられる。また、図 10 より、1/120 rad. 以降において両者の差はほぼないことから、この変形レベル以降は $\mathrm{P}-\Delta$ 効果の影響があるといえる。

なお、本報では鉛直荷重により柱脚接合部に付加される軸力の影 響は検討の対象外としたが、鉛直荷重の影響を詳細に調べるには必
要な検討事項で今後の課題である。

\section{4. 数值解析による木質ラーメンの構造性能の算定}

\section{1 解析モデル}

図 11 は解析モデルの諸元である。解析には、任意形状立体フレー ムの弾塑性解析プログラム S N A P を用い、せん断変形や P $-\Delta$ 効 果を考慮した平面フレーム解析とし、強制変位増分による 1 方向非 線形解析を行った。柱頭・柱脚接合部の曲げモーメントに対する復 元力特性は、剛域を設定した回転バネのモデルとした。

\section{2 接合部の復元力特性}

本報で採用する復元力特性の設定方法を示す。既報 ${ }^{3)}$ の要素試験 より、各接合部の復元力特性を設定するモーメントー回転角関係を 求めるせん断スパンの長さは、架構の階高やスパンの $1 / 2$ 付近と する。これにより、これらを反曲点位置とした時のせん断力の影響 を考慮した、接合部の復元力特性が得られる。図 6 の架構の場合、 図 5 の柱頭接合部 C T 15 、柱脚接合部 C B 12 が該当し、剛域を 設定した補正スパン $\mathrm{H}_{2}$ で評価した試験体 6 体のモーメントー回転角 関係の平均の包絡線を完全弾塑性評価して得られる折曲点での特性 值、寸なわち、曲げモーメント（M）と回転角（ $\theta$ ）の座標は図 12 のように定めた。各接合部とも初期剛性 $\mathrm{K}_{1 / 120}$ は 1/120 rad. 時の割線 剛性とし、降伏曲げモーメント $\mathrm{M}_{\mathrm{y}}$ は完全弾塑性評価の值、 $\mathrm{M}_{\mathrm{y}}$ での回 転角 $\theta_{\mathrm{y}}$ は $\mathrm{M}_{\mathrm{y}} / \mathrm{K}_{1 / 120}$ とした。柱頭接合部では、 $\mathrm{M}_{\mathrm{y}}$ と最大曲げモーメン ト $\mathrm{M}_{\text {max }}$ と結ぶbi-1inear としたのに対し、柱脚接合部では、 $\mathrm{M}_{\text {max }}$ まで を $\left(\theta_{y}, M_{y}\right) 、\left(\theta_{A}, M_{A}\right)$ の 3 点で結ぶ tri-1inear として $M_{\max }$ 以降は終局回 転角 $\theta_{\mathrm{u}}$ を通るよう直線的に耐力低下させた。なお、 $\theta_{\mathrm{A}}$ は $\theta_{\mathrm{y}}$ と $\theta$ 


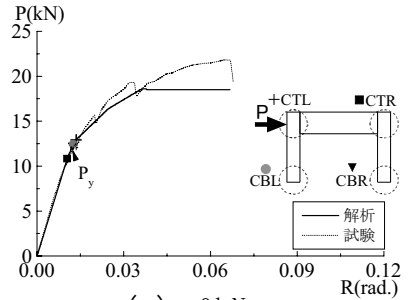

(a) $0 \mathrm{kN}$

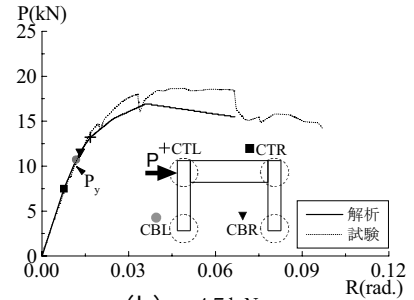

(b) $45 \mathrm{kN}$

図 14 解析と試験の比較

表 2 解析と試験の比較一覧

\begin{tabular}{|c|c|c|c|c|c|}
\hline & & \multicolumn{2}{|c|}{$4 \mathrm{P}-0$} & \multicolumn{2}{|c|}{$4 \mathrm{P}-45$} \\
\hline & & $\begin{array}{l}\text { 解析 } \\
1008\end{array}$ & 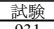 & 解析 & $\begin{array}{ll}\text { 試驗 } \\
867\end{array}$ \\
\hline $\mathrm{K}$ & (kN/rad.) & 1008 & 931 & 917 & 867 \\
\hline $\mathrm{P}_{\mathrm{u}}$ & $(\mathrm{kN})$ & 17.67 & 19.76 & 15.84 & 17.84 \\
\hline$\mu$ & & 3.807 & 3.150 & 3.864 & 3.251 \\
\hline$P_{\max }$ & $(\mathrm{kN})$ & 18.55 & 21.83 & 16.91 & 19.03 \\
\hline$P_{y}$ & \multirow{5}{*}{$(\mathrm{kN})$} & 12.03 & 12.86 & 10.21 & 11.81 \\
\hline (2) $0.2 \mathrm{P}_{\mathrm{u}} \sqrt{ }(2 \mu-1)$ & & 9.09 & 9.07 & 8.22 & 8.35 \\
\hline $2 / 3 \mathrm{P}_{\max }$ & & 12.37 & 14.55 & 11.27 & 12.69 \\
\hline$P_{1 / 120}$ & & 8.64 & 8.99 & 8.08 & 7.85 \\
\hline $\min (1) \sim(4))$ & & 8.64 & 8.99 & 8.08 & 7.85 \\
\hline
\end{tabular}

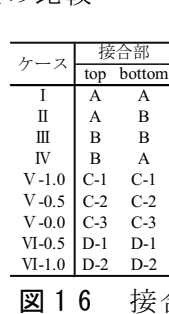

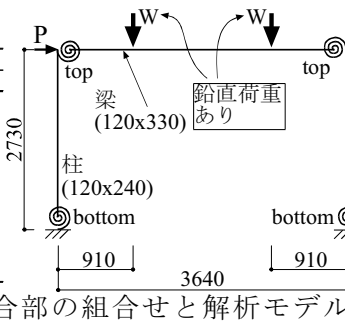

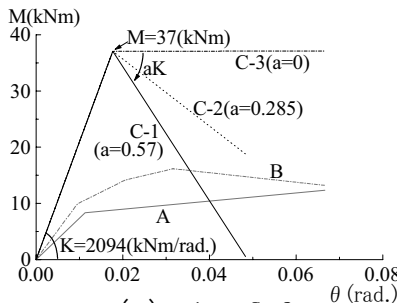

(a) $\mathrm{A} \sim \mathrm{C}-3 \quad \theta$ (rad.)

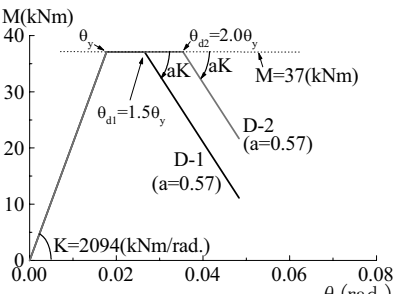

(b) $\mathrm{D}-1, \mathrm{D}-2 \quad \theta$ (rad.)
$M_{\max }$ の平均で、 $M_{A}$ は $\theta_{A}$ での曲げモーメントである。図 13 に各接合部 の復元力特性を、C T 15 、 C B 12 のモーメント一回転角関係の 平均の包絡線と併せて示す。平均值とした理由は、本報では各特性 值を試験結果のばらつきを除いた平均值で評価するためである。

ここで、鉛直荷重により付加される梁端部のせん断力や柱軸力の 影響は、復元力特性には考慮していない。これは、鉛直荷重で付加 される力を忠実に再現した接合部の要素試験は特殊で、また解析モ デルも複雑になるため、実務設計で扱うには不向きである。よって 本報では、鉛直荷重で付加される力を考慮せずに比較的容易にでき る要素試験で得られた復元力特性を使って、簡易な解析モデルの解 析結果で試験結果をどの程度再現できるかを調べることとする。

\section{3 解析結果}

試験結果の平均の包絡線と弾塑性解析の包絡線を図 14 に、解析 結果の包絡線を完全弾塑性で評価した特性值一覧を、試験結果の平 均值と併せて表 2 に示寸。なお、解析での終局変形角 $\mathrm{R}_{\mathrm{u}}$ も試験での 評価と同様に $1 / 15 \mathrm{rad}$ をを上限とした。

鉛直荷重の有無によらず、 $\mathrm{P}_{\max } 、 \mathrm{P}_{\mathrm{u}} 、 \mathrm{P}_{\mathrm{y}}$ の解析值は試験值より低く、 $\mathrm{K}$ は高くなった。また、解析值の方が $\mu$ は高めとなったが $\mathrm{P}_{\mathrm{u}}$ は低く、 それらが相殺されて $0.2 \mathrm{P}_{\mathrm{u}} \sqrt{ } \sqrt{ }(2 \mu-1)$ は試験值と概ね一致したと考え られる。一方、鉛直荷重の有無で $\mathrm{P}_{1 / 120}$ の傾向が異なり、鉛直荷重な しでは解析值が若干低め、鉛直荷重ありでは若干高めとなったが概 ね適切に評価できた。これらの結果より、本報で検討した範囲にお いて、鉛直荷重で付加される梁端部せん断力や柱軸力を考慮しない 簡易な復元力特性を用いた数值解析で、鉛直荷重を考慮した架構の 挙動は概ね再現できた。

図 14 に示した各接合部が降伏モーメント $\mathrm{M}_{\mathrm{y}}$ に到達した時点の荷 重一変形角関係の解析結果を、図 8 の試験結果と比較する。鉛直荷 重ありの場合では、最初に柱頭接合部が降伏した時の架構のせん断 耐力は、解析值の方が試験值より高くなったものの、鉛直荷重の影 響で曲げモーメントがオフセットされて接合部が早期に降伏する傾 向は、試験と同様であった。

\section{5. 実務設計での木質ラーメンの構造性能評価における解析的検討 5. 1 接合部の勒性と鉛直荷重を考慮した架構のせん断耐力}

4 章までで、架構が鉛直荷重を負担する時の挙動を試験と解析で 明らかにした。2 章で対象とした架構の接合部は柱頭・柱脚ともに
図 15 想定する復元力特性

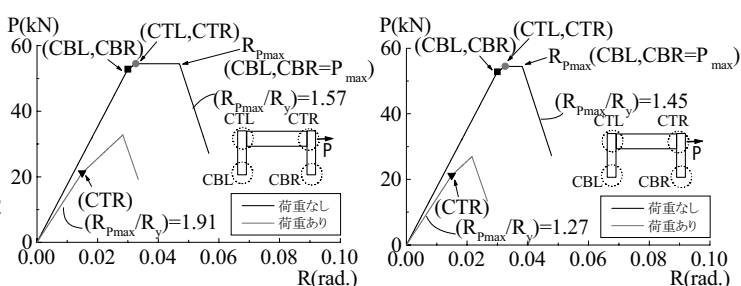

(b) $\mathrm{VI}-0.5$

$$
\text { 図 } 17 \mathrm{P}-\mathrm{R} \text { 関係 }
$$

表 3 解析結果一覧

\begin{tabular}{|c|c|c|c|c|c|c|c|c|c|c|c|c|c|c|c|}
\hline & \multicolumn{3}{|c|}{ （1)鉛直荷重丸し } & \multicolumn{3}{|c|}{$\begin{array}{c}\text { (2)鉛直何重奶) } \\
\text { P- } \Delta \text { 効果なよし }\end{array}$} & \multicolumn{3}{|c|}{$\begin{array}{c}\text { (3)鉛直何重妨り } \\
\text { P- } \Delta \text { 効果奻) }\end{array}$} & \multicolumn{3}{|c|}{$\mathrm{i}:$ (2)/(1) } & \multicolumn{3}{|c|}{ ii :(3)/(1) } \\
\hline & $\mathrm{P}_{\mathrm{u}}$ & $\mu$ & $\begin{array}{c}0.2 \mathrm{P}_{\mathrm{u}} \\
\times \sqrt{(2 \mu-1)} \\
\end{array}$ & $\mathrm{P}_{\mathrm{u}}$ & $\mu$ & $\begin{array}{c}0.2 \mathrm{P}_{\mathrm{u}} \\
\times \sqrt{(2 \mu-1)} \\
\end{array}$ & $\mathrm{P}_{\mathrm{u}}$ & $\mu$ & $\begin{array}{c}0.2 \mathrm{P}_{\mathrm{u}} \\
\times \sqrt{(2 \mu-1)} \\
\end{array}$ & $\mathrm{P}_{\mathrm{u}}$ & $\mu$ & $\begin{array}{c}0.2 P_{u} \\
\times \sqrt{(2 \mu-1)} \\
\end{array}$ & $\mathrm{P}_{\mathrm{u}}$ & $\mu$ & $\begin{array}{r}0.2 \mathrm{P}_{\mathrm{u}} \\
\times \sqrt{(2 \mu-1)} \\
\end{array}$ \\
\hline I & \begin{tabular}{|l|l}
15.09 \\
\end{tabular} & 3.621 & 7.54 & \begin{tabular}{|l}
15.29 \\
\end{tabular} & 3.081 & 6.95 & 11.92 & 3.817 & 6.14 & \begin{tabular}{|l|}
1.01 \\
\end{tabular} & 0.85 & 0.92 & 0.79 & 1.05 & 0.81 \\
\hline II & $\mid$\begin{tabular}{|l}
18.24 \\
\end{tabular} & 3.487 & 8.91 & 18.31 & 3.167 & 8.46 & 15.10 & 3.563 & 7.47 & 1.00 & 0.91 & 0.95 & 0.83 & 1.02 & 0.84 \\
\hline III & 21.41 & 3.339 & 10.20 & 21.22 & 3.163 & 9.79 & 18.28 & 3.220 & 8.53 & 0.99 & 0.95 & 0.96 & 0.85 & 0.96 & 0.84 \\
\hline IV & 18.22 & 3.454 & 8.86 & 18.03 & 3.212 & 8.40 & 14.75 & 3.651 & 7.41 & 0.99 & 0.93 & 0.95 & 0.81 & 1.06 & 0.84 \\
\hline V-1.0 & \begin{tabular}{|ll}
48.78 \\
\end{tabular} & 1.216 & 11.68 & \begin{tabular}{|l|l|}
24.14 \\
\end{tabular} & 1.249 & 5.91 & 19.66 & 1.188 & 4.61 & \begin{tabular}{|l}
0.49 \\
\end{tabular} & 1.03 & 0.51 & 0.40 & 0.98 & 0.40 \\
\hline$V-0.5$ & 48.90 & 1.512 & 13.91 & 33.10 & 2.408 & 12.93 & 23.58 & 2.400 & 9.19 & \begin{tabular}{|l}
0.68 \\
\end{tabular} & 1.59 & 0.93 & 0.48 & 1.59 & 0.66 \\
\hline$V-0.0$ & 54.46 & 2.159 & 19.84 & 51.57 & 2.102 & 18.46 & 34.05 & 2.791 & 14.57 & 0.95 & 0.97 & 0.93 & 0.63 & 1.29 & 0.73 \\
\hline VF 0.5 & \begin{tabular}{|l}
52.57 \\
\end{tabular} & 1.409 & 14.17 & \begin{tabular}{|l|l}
31.17 \\
\end{tabular} & 1.386 & 8.30 & 24.60 & 1.365 & 6.47 & \begin{tabular}{|l}
0.59 \\
\end{tabular} & 0.98 & 0.59 & \begin{tabular}{|l}
0.47 \\
\end{tabular} & 0.97 & 0.46 \\
\hline VH-1.0 & 53.40 & 1.678 & 16.39 & 37.10 & 1.518 & 10.59 & 28.59 & 1.530 & 8.21 & 0.69 & 0.90 & 0.65 & 0.54 & 0.91 & 0.50 \\
\hline
\end{tabular}

勒性は比較的高いが、実際には脆性的な性状の接合部形式5) 6) 他もあ る。この場合は勒性が低いので、架構のせん断耐力は終局時耐力 $0.2 \mathrm{P}_{\mathrm{u}} \sqrt{ } \sqrt{(2 \mu-1)}$ で決定されると考えられ、鉛直荷重を負担するとさ らに下がると予想される。そこで接合部の勒性に着目して、図 15 の ように勒性が高い接合部から脆性的な接合部までを想定する。そし てこれらを図 16 のように組合せた解析モデルの架構について、鉛 直荷重の影響を考慮した終局耐力 $\mathrm{P}_{\mathrm{u}}$ と塑性率 $\mu$ を弾塑性解析から求 め、違いを検討する。図 15 の A、B の各特性值は、それぞれ図 13 のC T L、C B に対応する。また、鉛直荷重の影響を詳細に調べる ため、(1)鉛直荷重なし、(2)鉛直荷重あり+ P - $\Delta$ 効果なし、(3)鉛直 荷重あり $+\mathrm{P}-\Delta$ 効果ありの 3 通りの解析を行う。接合部の特性值 の定量的な違いを無視するために、鉛直荷重は各接合部の長期の許 容曲げモーメントに相当する荷重とし、各ケースにおいて(1)を基準 とした(2)、(3)それぞれの比率を比べる。なお、図 15 (a) 中 C-1 は文 献 5 ) をモデル化した最も負勾配が急な脆性的な接合部である。これ を基準として C-2、C-3 は負勾配を緩くした接合部、D-1、D-2 は勒性 をある程度確保した復元力特性を想定している。

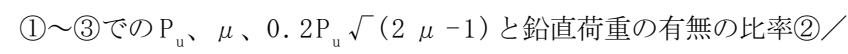
(1)、(3)/(1)を表 3 に示寸。なお、終局変形角 $\mathrm{R}_{\mathrm{u}}$ は 1 ケ所の接合部の 耐力が消失した時点の変形角とし、かつ $1 / 15 \mathrm{rad}$ ，を上限とした。

表 3 中 ii より、図 15 の比較的勒性が高い接合部で構成された I 〜 IVでは鉛直荷重により $0.2 \mathrm{P}_{\mathrm{u}} \checkmark(2 \mu-1)$ が $0.81 \sim 0.84$ となるのに対 し、脆性型の接合部で構成されるVは負勾配に応じて $0.40 \sim 0.73$ と大きく低下している。また、 I 〜 IVの比率が V - 0.0 より高いこ とから、降伏以降の耐力が上昇寸る接合部で構成される架構におい て、鉛直荷重による $\mathrm{P}_{\mathrm{u}}$ や $\mu$ の低下の割合は、降伏以降に耐力が一定 となる接合部で構成されるケース V-0.0 が最大である。一方、鉛 直荷重ありのVと VI-0.5、VI-1.0 では一部で $\mu$ が上昇するケース 


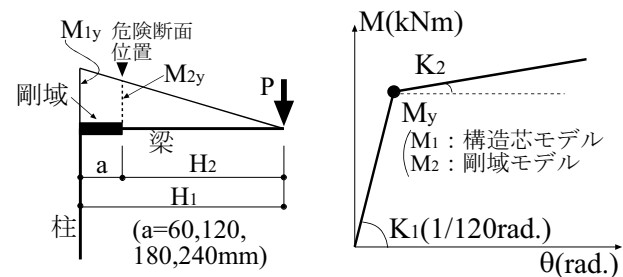

図 18 危険断面位置を考慮した復元力特性

も見られたものの、接合部の性状によらず鉛直荷重の影響で $P_{u} 、 \mu$ とも低下しており、特に $\mathrm{P}_{\text {u }}$ の低減が顕著であった。 $\mathrm{P}-\Delta$ 効果を 除いた鋁直荷重による低減を調べると、表 3 中 i より、VI-0.5、VI1. 0、V - 1.0 以外は概ね $0.92 \sim 0.96$ 程度である。

次に、鉛直荷重が架構に影響を与える因子として、3．3 と同様 にP - $\Delta$ 効果と接合部の早期の降伏に着目し、それぞれが占める割 合を調べる。これは、1.00 から i と ii それぞれの比率を差し引いた 值を比べれば分かる。鉛直荷重により架構のせん断耐力が低下寸る 際、 $\mathrm{P}-\Delta$ 効果の占める割合は約 $50 \%$ 以上であった。一方、VIと、 脆性的な性状の接合部のうち負勾配が最大の $\mathrm{V}-1.0$ は、 $\mathrm{P}-\Delta$ 効 果よりも接合部が早期に耐力低下寸る影響の方が大きかった。

以上のことから、本節で検討した範囲において、0.2 $\mathrm{P}_{\mathrm{u}} \sqrt{ }(2 \mu-1)$ は鉛直荷重の影響で低下寸ることが確認された。そして、脆性的な 接合部で構成される架構ではその傾向が顕著なことから、このよう な場合は特に鉛直荷重の影響を考慮すべきである。

次にVIに着目し、接合部が降伏から耐力低下寸るまでの変位と架 構全体の変形能力を考察する。図 17 は、鉛直荷重を変数としたVI の荷重一変形角関係、接合部の最初の降伏変形角 $\mathrm{R}_{\mathrm{y}}$ および最大耐力 時の変形角 $\mathrm{R}_{\mathrm{P} \max }$ とその比率 $\left(\mathrm{R}_{\mathrm{P} \max } / \mathrm{R}_{\mathrm{y}}\right)$ である。本報で検討した範囲に おいて、以下の知見が得られた。鉛直荷重ありの場合は柱頭接合部 が 1 箇所のみ降伏して最大耐力に到達し、 $\mathrm{R}_{\mathrm{P} \max } / \mathrm{R}_{\mathrm{y}}$ はVI-0.5 で 1.45 、 $\mathrm{VI}-1.0$ で 1.91 となっており、概ねそれぞれに対応する接合部での 復元力特性の回転角の比率 $\theta_{\mathrm{d} 1} / \theta_{\mathrm{y}}=1.50 、 \theta_{\mathrm{d} 2} / \theta_{\mathrm{y}}=2.00$ に近くなっ た $\left(\theta_{\mathrm{d} 1} 、 \theta_{\mathrm{d} 2}\right.$ の定義は図 $15(\mathrm{~b})$ 参照 $)$ 。これより、鉛直荷重の影響 で最大耐力に到達するまで、接合部が 1 箇所しか降伏しない架構に おいて、接合部降伏から最大耐力時の変形角の比率 $\mathrm{R}_{\mathrm{P} \max } / \mathrm{R}_{\mathrm{y}}$ は、接合 部の復元力特性での回転角の比率 $\theta_{\mathrm{d}(1,2)} / \theta_{\mathrm{y}}$ と概祊一致する。一方、 鉛直荷重なしの場合では、先に柱脚接合部が 2 箇所同時に降伏した ため、鉛直荷重ありと比べて $\mathrm{R}_{\mathrm{y}}$ が概ね 2 倍となり、 $\mathrm{R}_{\mathrm{P} \max } / \mathrm{R}_{\mathrm{y}}$ はVI-0.5 で1.27、VI-1.0で 1.57 となった。
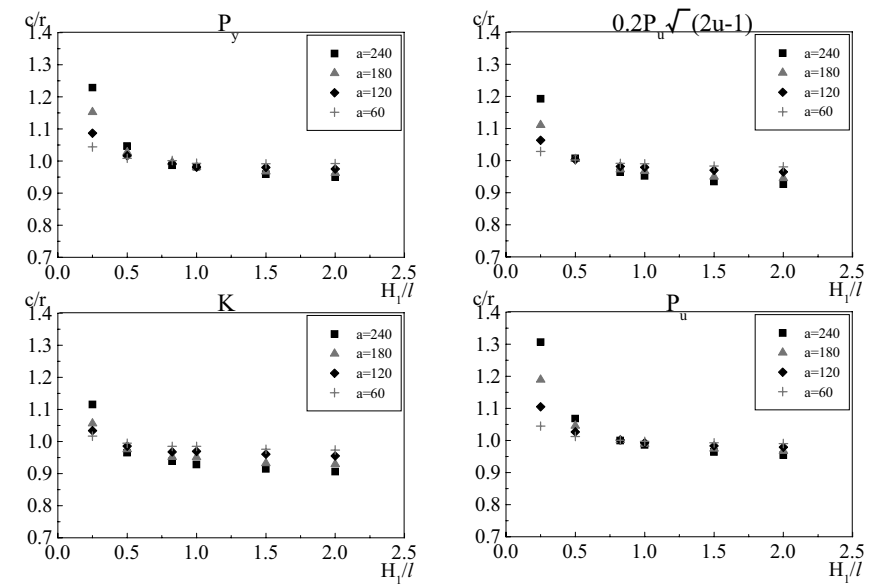

図 20 剛域モデルに対する構造芯モデルの比率と荷重一変形角関係の一例（鉛直荷重なし）

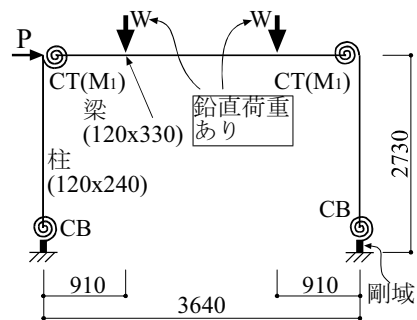

(b) 構造芯モデル
図 19 解析モデル

5. 2 接合部のせん断スパンならびに危険断面位置と架構のせん 断耐力との関係

鉛直荷重を負担する架構が水平力を受けると、梁の反曲点位置は 大きく変動しせん断スパンが極端に短くなるケースもある。危険断 面位置での接合部の復元力特性が（1）式で求まる場合は、せん断 スパンが短く作用するせん断力が大きいほど負担できる曲げモーメ ントが小さくなる。そのため、要素試験でのせん断スパンを短めに 設定しておけば、得られる復元力特性はせん断力の影響を考慮した 上でせん断力に対して襒しい条件になり負担できるモーメントも小 さくなるので、接合部の性能を危険断面位置で評価しなくても一見 安全なように考えられる。そこで本節では、1 章で述べたように適 切にモデル化されない接合部の復元力特性を用いる影響や、せん断 スパンの短い要素試験の結果から求めた復元力特性を用いること が、剛域を設けた場合と比べて安全側な評価となるか検討する。本 節では柱頭接合部に着目し、危険断面位置が柱梁部材の構造芯にな い仕様を想定し、架構のスパンに対する要素試験のせん断スパンの 比率を変数として剛域を設定し、危険断面位置で復元力特性を求 め、架構の構造性能を弾塑性解析で算定する (以降、剛域モデル)。 これに対し、接合部を適切にモデル化しない場合として剛域を設定 せずに復元力特性を構造芯で求めた架構（以降、構造芯モデル）の 構造性能も同様に求める。そして鉛直荷重の有無を変数にして、 剛域モデルと構造芯モデルの結果を比較する。

せん断スパンや剛域を変数とした柱頭接合部の復元力特性は、要 素試験を行う代わりに以下の方法で定めた。降伏モーメント $\mathrm{M}_{\mathrm{y}}$ は、 図 18 のように $\mathrm{M}_{2 \mathrm{y}}$ の位置を危険断面位置とし、この位置での $\mathrm{M}_{\mathrm{y}}$ が (1) 式で与えられる仕様の接合部を想定している。（1）式を変形した （3）式により、せん断スパン $\mathrm{H}_{2}$ を変数とした $\mathrm{M}_{2 \mathrm{y}}$ を算定できる。

$$
M_{2 y}=1 / \sqrt{\left(1 / M_{0}^{2}\right)+\left(1 /\left(H_{2} \cdot Q_{0}\right)^{2}\right)} \quad \text { (3) }
$$

ここで、 $M_{0} と Q_{0}$ は既報 ${ }^{3)}$ の純曲げおよび純せん断試験で求めた值
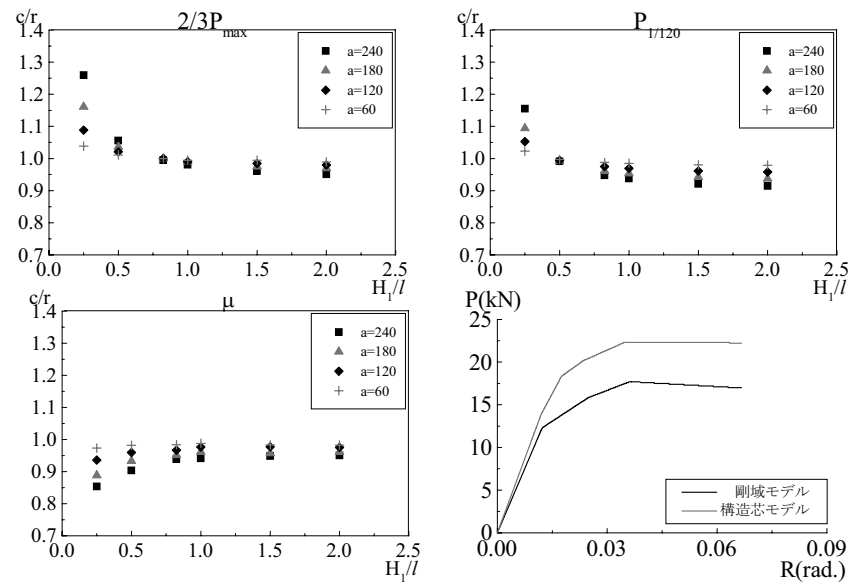

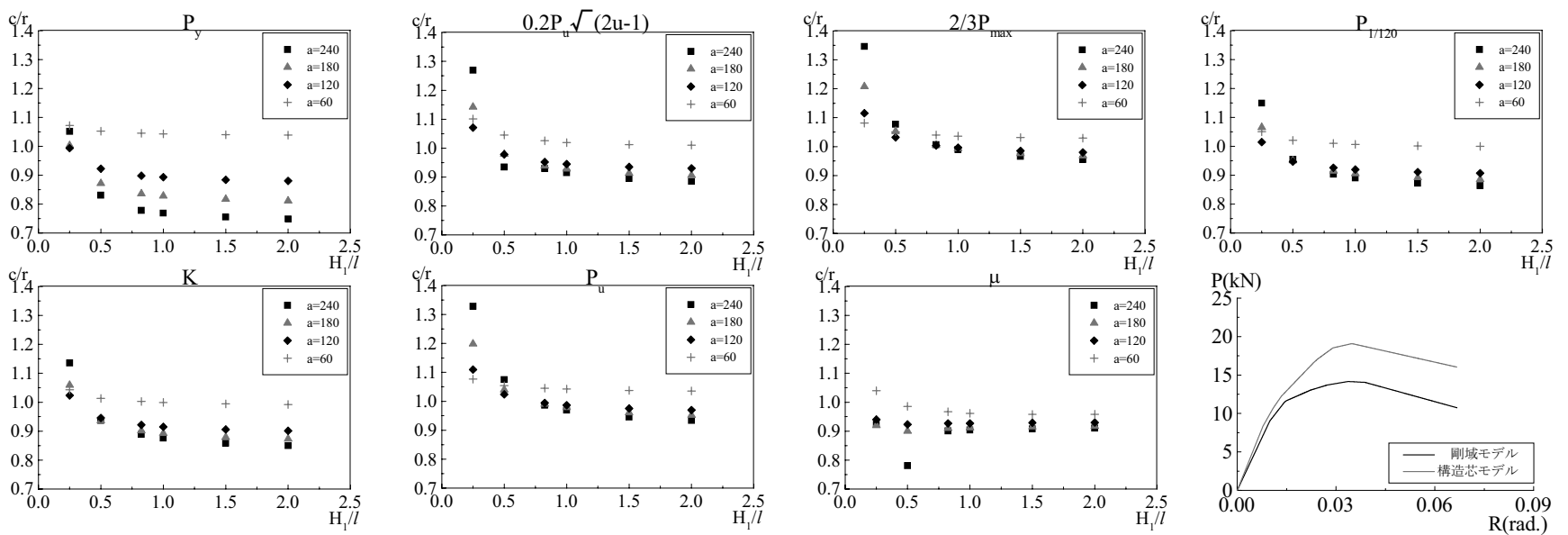

図 21 剛域モデルに対する構造芯モデルの比率と荷重一変形角関係の一例 (鉛直荷重あり)

でそれぞれ $8.27 \mathrm{kNm} 、 42.10 \mathrm{kN}$ とした。構造芯での曲げモーメント $\mathrm{M}_{1 \mathrm{y}}$ は図 18 のように直線で外挿して求めた。

本節で採用寸る柱頭接合部の復元力特性は、左右の柱頭とも図 13 のC T L とした。初期剛性は $1 / 120 \mathrm{rad}$ 。の割線剛性とする。割線剛 性を求めるための $1 / 120 \mathrm{rad}$. 時の曲げモーメント $\mathrm{M}_{1 / 120}$ は、図 13 のC T L から求めた降伏モーメント $M_{\mathrm{y}}$ と $1 / 120 \mathrm{rad}$. 時のモーメントの比 率を、（3）式で算定した $\mathrm{M}_{2 y}$ に乗じて求め、回転角は共通で構造芯 での值とした。2 次勾配 $\mathrm{K}_{2}$ と初期剛性 $\mathrm{K}_{1 / 120}$ の比率 $\beta$ は、剛域モデル、 構造芯モデルとも共通で図 13 のC T L の結果を採用した。なお、柱 脚接合部の復元力特性は、共通で図 13 のC B とした。

架構スパン $\mathrm{L}=3640 \mathrm{~mm}$ の $1 / 2$ (以降、 $l(=\mathrm{L} / 2))$ において、剛域長 $\mathrm{a}$ 公称スパン $\mathrm{H}_{1}$ を変数として求めた各特性值について、図 19 に解析 モデルを、図 20 に剛域モデル $\mathrm{r}$ に対する構造芯モデル $\mathrm{c}$ との比率(以 降、 $c / r$ ) を示す。 $H_{1} / l$ がおよそ 1.00 から 0.50 を境として、 $H_{1} / l$ に対 する $\mathrm{c} / \mathrm{r}$ のばらつきの傾向が異なった。まず、 $\mathrm{H}_{1}$ が短くなり $\mathrm{H}_{1} / l$ が 小さくなるほど、剛域モデルより構造芯モデルの方が $\mu$ は低く、 $\mu$ 以外は高くなりばらつきも大きくなった。これに対し、 $\mathrm{H}_{1}$ が長くな り $\mathrm{H}_{1} / \mathrm{l}$ が大きくなるほど逆の傾向となりばらつきも小さかった。ま た $\mathrm{H}_{1} / l$ の大小によらず、剛域モデルで剛域長が長いほど $\mathrm{c} / \mathrm{r}$ が 1.00 より離れる傾向となった。一例として $\mathrm{a}=240 \mathrm{~mm}$ で $H_{1} / l=0.25$ の荷重一 変形角関係を図 20 に示寸。次に、柱頭接合部が長期の許容曲げモー メントとなる鉛直荷重を載荷した各特性值の比率を図 21 に示寸。 鉛直荷重は構造芯モデルで弾性解析により求めた值とし、詳細は 3. 1 と同じである。傾向の概要は鉛直荷重なしの結果と概ね一致

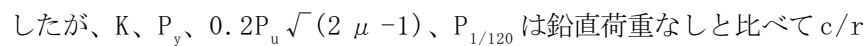
の差に開きがみられた。特に $\mathrm{P} 、$ ではその傾向が顕著であり、剛域長 が $120 \mathrm{~m} \mathrm{~m}$ 以上の剛域モデルで剛域長が長いほど差が大きくなった。

一例として、 $\mathrm{a}=240 \mathrm{~mm}$ で $\mathrm{H}_{1} / l=0.25$ の荷重一変形角関係を図 21 に示す。

本節での検討範囲において、架構のスパンに対してせん断スパン を極端に短くした構造芯モデルの復元力特性を用いた場合は、剛域 モデルと比べて危険側になることが明らかとなった。特に、L S B 接合部のように剛域長が長い、寸なわち本来の危険断面位置が構造 芯から離れる仕様ほど、その傾向が顕著であると考えられる。つ まり、接合部の構造性能を要素試験で求める場合、せん断スパンを 短く設定することが必ずしも安全側になるとはいえない。実務設計 において、簡略化のためやむを得ず構造芯モデルとする場合は、せ ん断スパンを架構のスパンの $1 / 2$ 以上長めにすると特性值が低めに

評価される。しかし、架構の構造性能を適切に評価するには、接合 部の仕様に応じて適切にモデル化した解析モデルで算定する方が望 ましいといえる。

\section{6. まとめ}

木質ラーメンの構造性能を評価する際に、鉛直荷重の影響や危険 断面位置に着目し、本報で対象とした接合部仕様や試験、解析条件 の範囲において得られた知見を下記に示す。

鉛直荷重の有無を変数とした木質ラーメンの実大架構試験で架構 の構造性能を調べ解析結果と比較した。接合部の勒性の違いによ る鉛直荷重の有無での架構の終局時耐力に着目寸ると、 $\mathrm{P}-\Delta$ 効 果の影響や、脆性的な接合部で構成される架構は特に鉛直荷重の影 響が大きいことが確認できた。また、接合部の危険断面位置が柱梁 の構造芯とならない柱頭接合部で構成される架構の構造性能を、剛 域を設けて適切に評価した場合と構造芯とした結果を比較した。そ の結果、架構のスパンに対して短いせん断スパンの復元力特性で算 定すると危険側となる可能性が見出された。

以上のことから、数值解析で木質ラーメンの構造性能を算定する には、適切なモデル化に基づいた復元力特性を用いるのが望まし い。また、鉛直荷重を負担する場合は $\mathrm{P}-\Delta$ 効果や接合部が早期に 降伏することが架構の構造性能に影響を与えるので、これらのこと を考慮して評価すべきである。

\section{参考文献}

1) 渋江圭司、近田純生、三城繁伸、山口雅和 : 合板釷打ち接合を用いた木質 ラーメンフレームの開発【その $1 、 2$ 】、日本建築学会大会学術講演梗概集 構造III、C-1、pp. 149-152、2006.9

2) 宮田雄二郎、山口和弘、川原重明、稲山正弘 : プレカット加工を用いた引 きボルト式木質ラーメン構造の研究（その $1 、 2$ )、日本建築学会大会学術 講演梗概集 構造III、C-1、pp. 389-392、2008.9

3) 景山 誠、村上雅英、小松幸平 : 曲げモーメントとせん断力の複合応力を 受ける木質ラーメン接合部の構造性能評価法に関する研究、日本建築学会 構造系論文集、第 647 号、pp. 165-173、2010.1

4) 木質構造設計規準・同解説 一許容応力度 - 許容耐力設計法 - 日本建築 学会、pp. 108-109、2006. 12

5 ) 佐藤基志、五十田博、菅谷泰浩：接着ボルトを用いた木質ラーメンに関す る基礎実験、日本建築学会技術報告集、第 13 巻、第 26 号、pp. 539-544、2007. 12

6) 井戸田秀樹：接合面に山形加工を施した集成材モーメント抵抗接合部の提 案、日本建築学会構造系論文集、第598 号、pp. 117-123、2005.12

[2010 年 6 月 16 日原稿受理 2010 年 9 月 1 日採用決定 $]$ 